\title{
Factors That Influencing Informal Park and Ride Facility Choice in Indonesia: Case Study of Kendal Regency
}

\author{
Itrinna Fajar', Achmad Djunaedi² \\ ${ }^{1,2}$ Urban and Regional Planning Graduate Program, Gadjah Mada University, Yogyakarta, Indonesia \\ Correspondence e-mail: itrinna@gmail.com
}

\begin{abstract}
Abstrak. Park and Ride (titipan motor) menawarkan alternatif yang efisien untuk mengakses jalur-jalur utama dari daerah yang kepadatannya rendah. Di Kabupaten Kendal, fasilitas ini memungkinkan orang untuk memilih antara berkendara atau naik bus ketika mereka sampai di jalan nasional pantura. Model binary logit diterapkan karena alternatif pilihan fasilitas parkir dibatasi menjadi dua kategori fasilitas yaitu P\&R periferal dan P\&R lokal. Berdasarkan survei preferensi yang diolah oleh program R, hasil dari jenis pilihan fasilitas $P \& R$ dalam beberapa sekenario, variabel yang secara signifikan mempengaruhi perilaku pilihan $\mathrm{P} \& \mathrm{R}$ adalah jenis kelamin, biaya, kemudahan, layanan semalam dan jenis penggunaan spasial. Sedangkan faktor usia dan kapasitas tidak secara signifikan mempengaruhi pilihan tipe P\&R.
\end{abstract}

Kata kunci: park and ride; tipologi park and ride; perencanaan transportasi; manajemen permintaan transportasi; parkir

Abstract. Park and Ride offers an efficient alternative to accessing major transport nodes in low-density settings. In Kendal Regency these facilities allow people to choose between drive and ride bus when they arrive in national road.A stated preference survey was carried out to get insight how to improve utilization of local P\&R. Binary logit model is applied since the alternative of parking facility choice is limited into two categories peripheral $P \& R$ facilities and local $P \& R$ facilities. Based on stated preference survey processed by $R$ statistics, the result of type of P\&R facility choice under hypothetical scenarios as follow: (1) variables that significantly affect park and ride choice behavior are gender, cost, amenity, overnight service and type of spatial use. Whereas factor age and capacity do not significantly affect park and ride type choice. (2) Even though variable cost is significant, but the variable is insensitive to $P \& R$ type choice. While variable number of amenity is more sensitive to $P \& R$ type choice.

Keywords: park and ride; typology of park and ride; transport planning; transport demand management; parking

\section{INTRODUCTION}

Nowadays in every city more and more highways are being constructed. Government think that it will reduce traffic congestion, however more people buy cars and crowd that new road. Automobile dependence cause various problem from environmental problem until social problem. Smog, high greenhouse gases, oil vulnerability, acid rain, and urban sprawl are the example of those environmental problem. While social damage that people have to endure because car-culture oriented development are loss the community of neighborhood, suffer in road rage, loss of public safety. Understanding the consequences of automobile culture that is unsustainable many cities change their development transportation system paradigm, from driving return back to walking, cycling and public transport. Traffic demand management is applied to reduce unnecessary private vehicle use. It is often more economical than build new road. The spare budget can be invested to public transport infrastructure and safety measure for motorized driver, thus increase quality of life (Boaddus, et.al, 2009).

Travel demand management is described as a set of strategy to reduce and redistribute travel demand. Travel demand measure includes expanding public transport networks, improving the quality of public transport services, expanding cycle and pedestrian facilities and making them more attractive to use, investigating strategies to encourage shifts in travel from the private car to other modes. Public transport provides mobility for a wider range of people, including disabled, young and older people without cars. Thus government should develop public transport system that efficient in term space and energy, also be more cost effective than private cars, therefore automobile usage can be reduced, in order to do this there are two important concepts that have to be address, ((Boaddus, et.al, 2009).

1. Multi-modal; there are many modes of transportation provided such as, by foot, bicycle, public bus or transit to train, thus people can choose among them.

2. Intermodal; among transportation modes available, they must be connected each other. For example, mounting bicycle to bus or smooth transferring between bus to train station. The convenient of intermodal transfer will encourage people to commute by public transportation.

In Indonesia most of cities only develop roadbased transportation to serve their daily commuters except in Jakarta and Palembang that built light rapid transit by central government. This road-based public transport is central to economic growth of developing cities. For the majority of residents, road-based public transport (bus and paratransit) is the only means to access employment, education, and public services. In medium and large developing cities, such destinations are beyond viable walking and cycling distances while 
vast numbers of individuals have limited access to automobiles (Pojani and Stead, 2015). Unfortunately, the current state of road-based public transport services in many developing cities does not serve the mobility needs of the population adequately. They cannot be accessed by people in remote area. Park and ride is a travel demand management measure to solve the accessibility problem between remote area and central business district. Park and ride as transfer node is expected to redistribute travel demand.

$\mathrm{P} \& \mathrm{R}$ allows cities to increase the number of available parking spaces for the downtown area without using valuable land in the CBD core for parking lots or structures. Encouraging park and ride can also reduce downtown automobile congestion and the time that drivers spend waiting in traffic, thus reducing air pollution. There is the spatial mismatch between the residential and the employment concentration. The employees of the Central Business District come from all over other sub-district in Kendal Regency. With jobs concentrated in this sub-district, the commuting patterns of the trip makers tend to be that of morning and evening peak hours. According to M.J.Bruton and Jamilah M in Norlida et.al (2007) this condition has led to journey to work problems as well as congestion on some of the major roads leading into and out of the Central Busines District. With the over-utilization of the roads and highways as well as the limited capacity of these infrastructures in accommodating the increase in the traffic volume, the issue of accessibility to the industrial area has become one of the more pressing concerns of the city planners (Norlida et.al, 2007). The increasing dependence on private vehicles has indeed put pressure on the capability of the road network. In term spatial and transport interaction, Park and Ride and Transit Oriented Development catches different spatial area. Transit Oriented development catch the commuters who live around station neighborhood, until radius 1-2 kilometer from station or 5-10 minutes walking while Park and Ride catches commuters who live in further distance from station, more than 10 Kilometers (Ginn, 2009).

The use of Park-and-Ride facilities as a transport demand management has a long history around the world. First Park \& Ride (P\&R) locations emerged in the 1920s in the USA, initially always spontaneously, and later on as facilities planned by competent transport authorities (Krasic and Lanovic, 2013). In United States, Park-and-Ride has appeared since 1930s and in Unite Kingdom, Park-and-Ride was first introduced in 1960s. (Noel, 1988 in Wun, 2013)

Some cities that have park and ride programs include Pittsburgh, Pennsylvania; St. Paul, Minnesota; San Jose, California; and Norfolk, Virginia. ((Krasic and Lanovic, 2013). Other P\&R grows spontaneously without planning like in Zagreb. In Zagreb, just like in many other cities of Europe. People living in distant parts of the city, and residents of satellite towns and towns near Zagreb, have recognized the possibility of parking their vehicles along a public transport station, and resuming their travel by public transport. This also happened in Kendal Regency, people start to run business since they understand that people need place to keep their private vehicle before they ride public transportation.

Turnbul, et.al (2004) conducted preference surveys of park-and-ride and park-and-pool lot users have included questions on the reasons people choose these travel options over driving alone. The responses add further insight into the factors influencing use of these facilities. The four surveys reported on here were conventional user preference surveys. Taking the results of all four together, the major incentives come out to be saving money, saving on driving stress, and saving time. Saving of money and avoidance of driving stress seemed to rank higher on average than other factors, although this finding was not much consistency among surveys in order of preference,

Ginn (2009) found important factors that draw commuters use park and ride facilities. That factors include convenience, security, number of available facilities and ability to allow resident to live further away from stations. Wun (2013) classified into five categories, which are total journey cost, total journey time, convenience and reduction of stress, attributes of Park-and-Ride facilities and socioeconomic characteristics of users. This research aims to explore the characteristics of informal park and ride, what factors that affecting commuters to choose park in certain park and ride facility.

\section{METHOD AND RESEARCH}

Primary data is compiled by conducting several surveys. While secondary data is compiled from publication from official agency (Regional Planning Agency and National Transportation Agency). This research has conducted three surveys, first is census to all parking facilities that located along national road corridor. Second, revealed survey to informal park and ride users. Last, a stated preference sampling has been carried out to collect behavior data of park and ride users through online survey. Census is conducted by listing all park and ride facilities in arterial road of Kendal Regency. Samples is a part of population that its characteristics will be investigate and its characteristics is able to represent the population. Number of samples is usually less than number of populations. Random sampling technique is utilized to determine the number samples of this research. 204 people are interviewed to fill in revealed survey and 100 people willing to fill out online questionnaire for stated preference survey.

Analysis that employed in this study is binary logit regression analysis. This model is constructed to identify the significant factors that make a local park and ride interesting. 
Logit models are the most commonly used modal split models in the area of transportation planning, since they possess the ability to model complex travel behaviors of any population with simple mathematical techniques. The mathematical framework of logit models is based on the theory of utility maximization and is discussed in detail in Ben-Akiva and Lerman (Ben-Akiva and Lerman, 1985). This model assumes the utility function fits to Gumbel distribution, probability of a person i choose mode $n$, out of $M$ number of total available modes.

$P_{\text {in }}=\frac{\exp V_{\text {in }}}{\sum_{m \varepsilon M} \exp V_{i m}}$

$\mathrm{V}_{\text {in }}$ is the utility function of mode $\mathrm{n}$ for individual $\mathrm{i}$;

$V_{\text {im }}$ is the utility function of any mode $m$ in the choice set for an individual $\mathrm{i}$; $\mathrm{P}_{\text {in }}$ is the probability of individual $i$ selecting mode $n$; and $M$ is the total number of available travelling modes in the choice set for individual $\mathrm{i}$.

Binary logit model is applied since the alternative of parking facility choice is limited into two categories Peripheral Park-and-Ride facilities and local Park andRide facilities. The utility is generally represented as a linear function of the attributes of the $P \& R$ facility weighted by the coefficients which attempt to represent their relative importance as perceived by $P \& R$ users. In this study I assumed that age, gender, cost amenity, overnight service, $P \& R$ capacity, spatial use are possible factors that affect people to choose between Peripheral Park-and-Ride facilities and local Park and-Ride facilities. A possible mathematical representation of a utility function of a model is shown in equation below:

\section{$V=\beta_{0}+\beta_{1} X_{1}+\beta_{2} X_{2}+\cdots+\beta_{7} X_{7}$}

$\mathrm{V}$ is the net utility function of parking facility $\mathrm{m}$ for individual $\mathrm{i} ; \mathrm{X} 1, \ldots, \mathrm{X} 7$ are $\mathrm{P}$ number of attributes of parking facility for individual $\mathrm{i} ; \beta 0, \ldots, \beta 7$ are $\mathrm{P}$ number of coefficients (or weights attached to each attribute)

For model calibration, the maximum likelihood function definition and Newton-Raphson method is applied to estimate the parameters. T-value, hit ratio, and McFadden determination coefficient are selected as indices in this research. T-value can judge whether a single variable significantly affects the type of $P \& R$ choice result or not. In this research the confidence level is set at $90 \%$, the interval for $\mathrm{T}$-score value to be accepted should between

$-1.645 \geq \mathrm{T}$-score value $\leq 1.645$. Table Hessian matrix calculation is made to conduct t-value test. Parameters estimation process of utility equation is calculated use $\mathrm{R}$ software. $R$ is a free statistical program for various statistical method, chart even mapping

\section{RESULT AND DISCUSSION}

There are several ways to categorize of informal park and ride, however in my opinion the most important classification is based on distance, that are local $P \& R$ and peripheral $P \& R$. Based on revealed survey some people do not always choose the informal park and ride.

Facilities that closest to their home. Only 130 respondents $(63.7 \%)$ choose to closest informal park and ride facilities. 36.3\% respondent travel further away close to destination. Traveling further to destination cause problem, because they spend more time in private vehicle rather than high occupancy vehicle. The commuters still crowd the arterial road, that lead to traffic congestion.

A stated preference survey was carried out to get insight how to improve utilization of local P\&R. Several scenarios of hypothetical questions were asked to respondents that having daily commuters from Kendal Regency. Total 100 respondents participated on online survey that held from April 15, 2019 to April 27, 2019. They were asked to choose one between 2 sets of park and ride's attributes. There is no different number of respondent's gender, male was $50 \%$ and female $50 \%$ too. Age is categorized into 2 categories, young (0-29 years old) and old (>29 years old). The number of younger respondents was 48 people while the number of older respondents is 52 people. Every person answered 4 hypothetical question, hence there were 400 result answers. The park and ride attributes were changed into dummy variable in order to produce proper result.

Table 1. Respondents profile of stated preferences survey

\begin{tabular}{|c|c|c|c|c|}
\hline \multicolumn{3}{|c|}{ Variables } & \multirow{2}{*}{$\begin{array}{l}\text { frequency } \\
48\end{array}$} & \multirow{2}{*}{$\begin{array}{l}\text { Proportion } \\
(\%)\end{array}$} \\
\hline age & & $0-29$ & & \\
\hline & & $>29$ & 52 & 52 \\
\hline \multirow[t]{2}{*}{ gende } & & male & 50 & 50 \\
\hline & & female & 50 & 50 \\
\hline Result & type of & local & 244 & 61 \\
\hline P\&R & & peripheral & 156 & 39 \\
\hline
\end{tabular}

Source primary data

Table 2. Dummy variable annotation

\begin{tabular}{lll}
\hline dummy variable & notations & \\
\hline sex & female $=0$ & Male $=1$ \\
age & $0-29=0$ & 30 or more $=1$ \\
amenity & without amenity $=0$ & with amenity $=1$ \\
overnight parking & not possible $=0$ & possible $=1$ \\
capacity & $0-100=0$ & more than $100=1$ \\
spatial use & new building $=0$ & owner house $=1$ \\
result & peripheral $=0$ & local $=1$ \\
\hline
\end{tabular}

Source primary data

The choices of park and ride have been investigated using binary logit model. The data were processed by $\mathrm{R}$ program analysis. The program would select model that has the highest log likelihood value (roh value). Basically, the value of McFadden's Rho2 
varies between 0 (no fit) and 1 (perfect fit). According to Louviere et al., (2000) in Waerden, et .al (2015) roh values between 0.2 and 0.4 are considered to be indicative of 'extremely' good model fits. Another scientist, Hensher et al. (2005) in Waerden, et al (2015) said that a Rho 2 of 0.3 or higher represents a 'decent' fit for a discrete choice model. The adjusted Rho2 includes the number of parameters (or degrees-of-freedoms) used to compose the optimal model, in the calculations. In this study, the level of confidence are set $90 \%$. Thus, the T-score value of each factors of fit model should be between $-1.645 \geq \mathrm{T}$-score value $\leq 1.645$ for the attributes to be significant. For more detail, the result is presented in table 3 below.

Table 3. Output of $\mathrm{R}$ program analysis

\begin{tabular}{|c|c|c|c|c|c|c|c|c|}
\hline factor & $\begin{array}{c}\text { X1 } \\
\text { (age) }\end{array}$ & $\begin{array}{c}\text { X2 } \\
\text { (gender) }\end{array}$ & $\begin{array}{c}\mathbf{X 3} \\
(\cos t)\end{array}$ & $\begin{array}{c}\mathbf{X} 4 \\
\text { (amenity) }\end{array}$ & $\begin{array}{c}\text { X5 } \\
\text { (overnight } \\
\text { service) }\end{array}$ & $\begin{array}{c}\text { X6 } \\
\text { (capacity) }\end{array}$ & $\begin{array}{c}\text { X7 } \\
\text { (spatial } \\
\text { use) }\end{array}$ & $\begin{array}{c}\mathbf{X 8} \\
\text { (constant } \\
\text { value) } \\
\end{array}$ \\
\hline t-value & $\begin{array}{c}-0.54499 \\
\text { not } \\
\text { significant }\end{array}$ & $\begin{array}{c}1.78499 \\
\text { significant }\end{array}$ & $\begin{array}{c}-9.309 \\
\text { significant }\end{array}$ & $\begin{array}{c}6.606763 \\
\text { significant }\end{array}$ & $\begin{array}{c}2.881774 \\
\text { significant }\end{array}$ & $\begin{array}{c}0.42479 \\
\text { not } \\
\text { significant }\end{array}$ & $\begin{array}{c}-1.9212 \\
\text { significant }\end{array}$ & $\begin{array}{c}0.9001 \\
\text { not } \\
\text { significant }\end{array}$ \\
\hline co-efficient & -0.1721057 & 0.567442 & -0.0024 & 2.0537177 & 0.95269346 & 0.1542151 & -0.51222 & 0.290842 \\
\hline roh value & 0.352633 & \multicolumn{7}{|c|}{ able to explain park and ride choice } \\
\hline
\end{tabular}

Source primary data

Probability function model can be formulated as:

$$
\begin{aligned}
& P=\frac{1}{1+e^{\beta 0+\beta i X i}} \\
& \ln \left(\frac{P}{1-p}\right)=0.567442 X 2-0.0024 X 3+ \\
& 2.0537177 X 4+0.95269346 X 5-0.51222 X 7
\end{aligned}
$$

From the table 3 roh value is 0.352633 , indicate that he model is decently able to represent the respondents' observed choices. The variables that significantly affect park and ride choice behavior are gender, cost, amenity, overnight service and type of spatial use. Whereas factor age and capacity do not significantly affect park and ride type choice. The parameters' coefficients exhibit reasonable magnitudes and signs with respect to the utility equations. The utility equation were established such that a negative coefficient for variables meant that a rise in the attribute (which was cost in this case) decrease the probability of local park and ride utilization.

The variables in the mode choice model which are of primary interest to a transportation planner are the level-ofservice attributes. In addition to the use of a model for conventional area-wide forecasts, it can also be used to give indications of the likely effects of changes in the selected level-of-service variables, given that all other attributes remain constant (Khan, 2007). Such sensitivity analyses are expressed in terms of elasticity and provide useful information for both the development and general appraisal of possible new policies in the study area. For cost parameter because the coefficient is under 1 percent, the cost change in the graphic appear almost does not change the probability. The sensitivity of cost attribute presented in figure 1 .

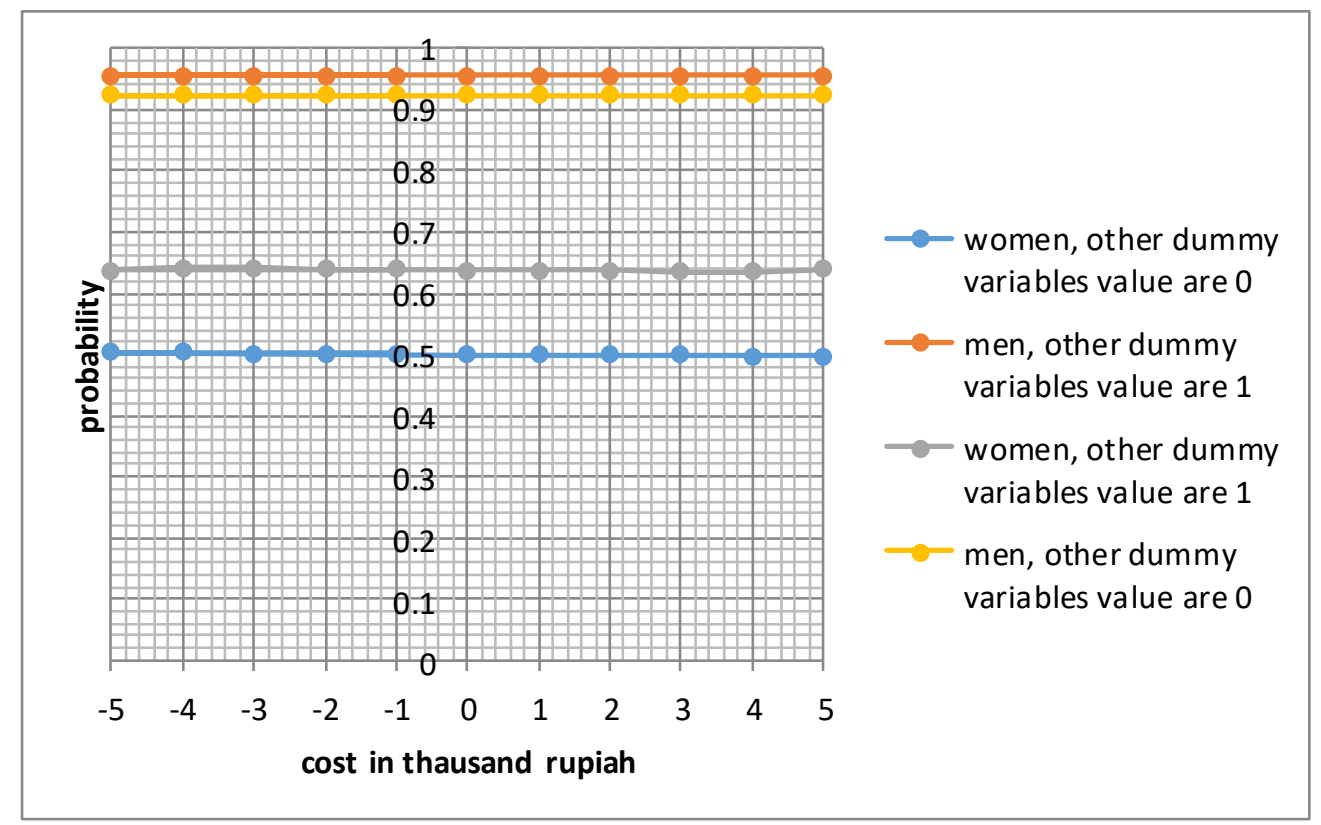

Figure 1. Sensitivity of cost attribute 
The number of amenity park and ride facility attracts more commuters to utilize the transportation facility. This finding is consistent to previous study about train-based P\&R in Perth, Australia, (Olaru.et.al, 2014) found that amenity of $P \& R$ facility near station affecting attractiveness of park and ride facility. The amenity attribute has positive coefficient, it translated that adding more amenity will increase probability park and ride users to use local P\&R. However, after third amenity, addition more amenity would not enhance the probability of local park and ride utilization. For more detail, the sensitivity of amenity attribute presented in figure 2 .

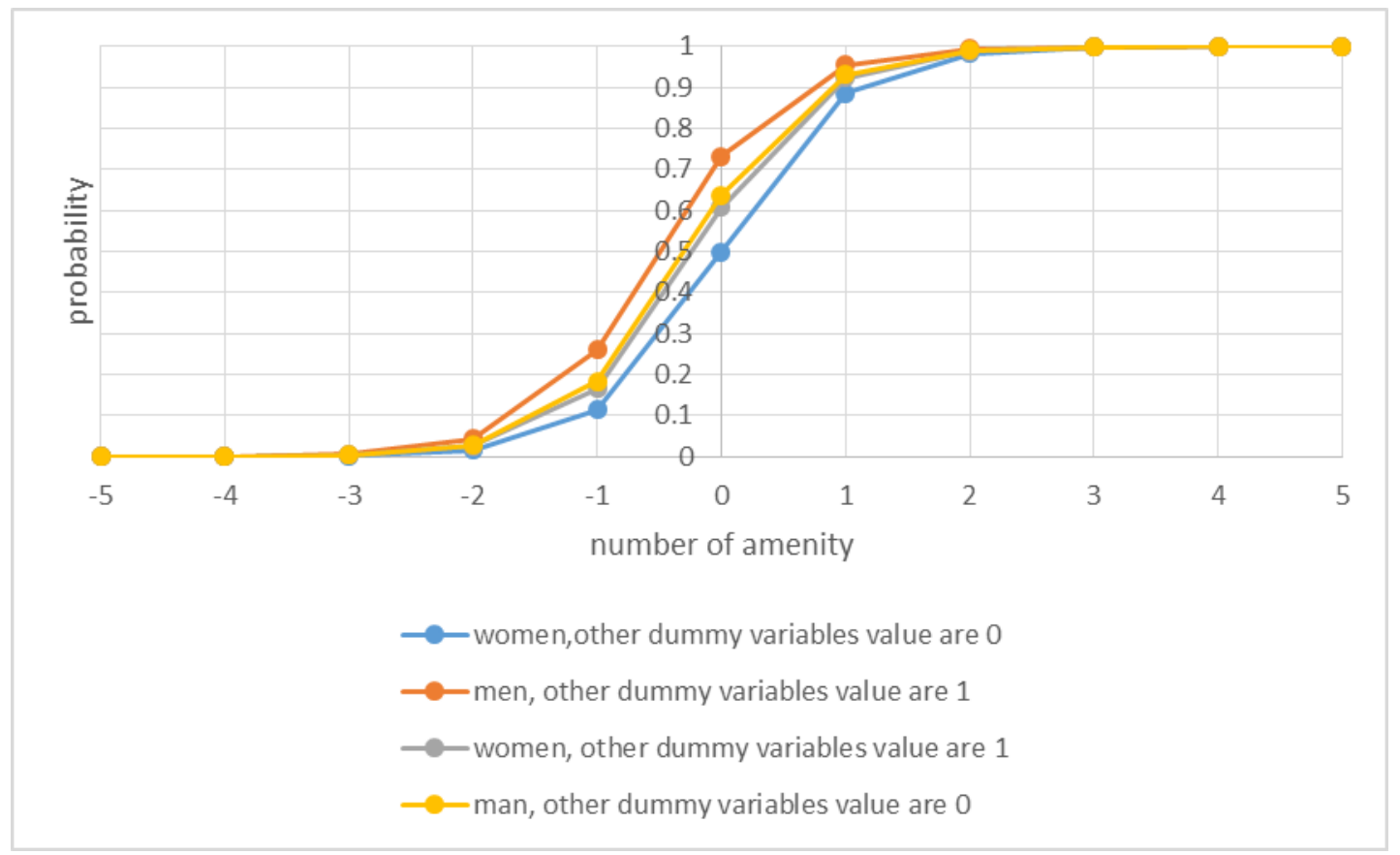

Figure 2. Sensitivity of amenity attribute.

In addition, the binary logit model result exhibits that male tend to choose local P\&R than female. The reason for this behavior, women possibly search for more convenient park and ride, the park and ride with better quality or amenity, thus they willing to travel more to park their vehicle in better park and ride. This result is correspondent to the research that conducted by Olsson (2003). She found that women regard more park and ride's amenity than men, furthermore are more willing to pay more to get more security in a park and ride facility.
In study area, local $\mathrm{P} \& \mathrm{R}$ has more $\mathrm{P} \& \mathrm{R}$ facilities with amenities than peripheral $P \& R$. From all 33 local $P \& R, 24$ facilities have amenity. However only 6 facilities from 11 peripheral $P \& R$ that have amenity, the percentage of peripheral $P \& R$ with amenity is lower than the percentage local $\mathrm{P} \& \mathrm{R}$ with amenity, $72.72 \%$ and $54.54 \%$ respectively. I think this the reason why respondents tend to choose local $\mathrm{P} \& \mathrm{R}$ over peripheral $P \& R$

Table 4. Number of local $P \& R$ and peripheral $P \& R$ with amenity and without amenity

\begin{tabular}{lcccc}
\hline type of P\&R & with amenity & percentage & without amenity & percentage \\
\hline local & 24 & $72.72 \%$ & 9 & $27.27 \%$ \\
peripheral & 6 & $54.54 \%$ & 5 & $45.54 \%$ \\
\hline
\end{tabular}

Furthermore, the model suggests commuters who use park and ride will go local park and ride that provide overnight parking since it more flexible time to park and pick their vehicle according to their schedule. Overnight service park and ride facilities are usually guarded by the owner of facility since they stay at home around the clock running the business. However, the last attribute, spatial use, the coefficient is negative. The probability of respondents go to local park and ride facility rises if facility is separate building from owner house. The separate building park and facility usually guarded by employee who has limited work time. Nevertheless, parking in separate building is more convenient since there is more space between parking vehicles.

Next the implication of this study result will be discussed. First, we must realize that this business is informal, home based enterprise, the owner set the parking lot in their own private home that located in 
strategic area such as near junction or artery road. The land in this area has high value, if an investor interested, the land will be converted to other usage that more profitable. Thus, in order to owner to preserve their business, government should give incentive to the owner to keep their business. If government does not give attention, this kind of business will disappear, and more commuters probably travel with low occupancy vehicle to final destination, consequently they will clog the arterial road.

Second, the final aim of the policy is to reduce overall low occupancy vehicles (private car and motorcycle) in main road, local P\&R locations should be preferred to peripheral ones. Not only would the magnitude of the unintended effects be lower, but by intercepting the motorists at an early stage, the density of traffic in arterial road will decrease. This study found that factors that significant affect the park and ride are gender, cost, amenity, overnight service, and type of spatial use. While age and capacity do not affect significantly park and ride type choice. In the future, for park and ride improvement or procurement new facility, those factors should be put into consideration.

\section{CONCLUSSION}

The variables that significantly affect park and ride choice behavior are gender, cost, amenity, overnight service and type of spatial use. Whereas factor age and capacity do not significantly affect park and ride type choice. Even though variable cost is significant, but the variable is insensitive to $P \& R$ type choice. While variable number of amenity more sensitive to $P \& R$ type choice.

In the future, for park and ride improvement or procurement new facility, factors gender, cost, amenity, overnight service, and type of spatial use should be put into consideration.

\section{ACKNOWLEDGEMENT}

This study is a result from Double Degree Program LINKAGE BAPPENAS, collaboration between Magister Perencanaan Wilayah dan Kota (MPWK) Universitas Gadjah Mada (UGM) and Graduate School of Science and Engineering Ritsumeikan University.

\section{REFERENCES}

Ben-Akiva, M.E., \& Lerman, S. R. (1985) "Discrete Choice Analysis: Theory and Application to Travel Demand" Cambridge, Mass, MIT Press

Broaddus. et.al. (2009). Transport Demand Management, training document. GTZ Transport Policy Advisory Service. Eschborn, Germany.

Ginn, S. (2009). The Application of The Park \& Ride and TOD concepts to develop a new framework that can maximise public transport patronage, (November), 301.
Hensher, D.A., Rose, J.M. \& Greene, W.H. (2005) Applied Choice Analysis: A Primer, Cambridge University Press, Cambridge, UK

Khan, O. A. (2007). Modelling passenger mode choice behaviour using computer aided stated preference data, 324. Retrieved from http://eprints.qut.edu.au/16500/1/Omer_Khan_Th esis.pdf

Krasić, D., Lanović, Z., \& Elipsa, -S Z. (2013). Park \&amp; Ride facility planning. Gradevinar, 65, 111-121.

Norlida, A. H., Jamilah, M., \& Mohamed Rehan, K. (2007). Parking duration of fringe Park-and-Ride users and delineation of stations catchment area: Case of the Kuala Lumpur conurbation. Journal of the Eastern Asia Society for Transportation Studies, 7, 1296-1310

Olaru,et.al. (2014). Travellers' Attitudes Towards Parkand-Ride (PnR) and Choice of PnR Station: Evidence from Perth, Western Australia. Procedia - Social and Behavioral Sciences, 162(Panam), 101-110. https://doi.org/10.1016/j.sbspro.2014.12.190

Olsson, A.-L. L. (2003). Factors That Influence Choice of Travel Mode in Major Urban Areas. the Attractiveness of Park \& Ride. Trita-Infra. Retrieved from http://media.lib.kth.se:8080/licengrefhit.asp?licnr $=1627$

Pojani, D., \& Stead, D. (2015). Sustainable Urban Transport in the Developing World: Beyond Megacities. Sustainability, 7(6), 7784-7805. https://doi.org/10.3390/su7067784

Turnbull, K. F., Evans, J. E., \& Levinson, H. S. (2004). Park and Ride/Pool: Traveler Response to System Changes. TCRP Report 95: Transportation System Changes.

Waerden, P., Lem, A., \& Schaefer, W. (2015). Investigation of factors that stimulate car drivers to change from car to carpooling in city center oriented work trips. Transportation Research Procedia, 10(July), 335-344.

Wun, Wong Tak .(2013).To Drive or to Park: Factors Affecting the Use of Park - and - Ride Facilities in Hong Kong. The University of Hong Kong. Dissertation 